\title{
Local food systems: potential for new market connections for family farming
}

\author{
Amanda Borges de Souza \\ Armando Fornazier \\ Mauro Eduardo Delgrossi
}

${ }^{1}$ University of Brasilia - UnB, Brasília, DF, Brazil.

II University of Brasília - UnB, Brasília, DF, Brazil.

III University of Brasilia - UnB, Brasília, DF, Brazil.

\begin{abstract}
In recent years, local food systems have come to be seen as a new possibility in creating markets for family farming. These systems are based on local production and consumption structures, with a primary focus on sustainability, locality and proximity. It is essential to understand the dynamics of these systems and their impact in the context of family farmers. Thus, this article seeks to identify in the literature the main theories and concepts used in the analysis of "local food systems", verifying the state of the art of its theoretical elements related to the concept of "family farming" in Brazilian and international academia. The methodological procedure employed was a systematic literature review following the Methodi Ordinatio protocol, covering 30 articles indexed in the search portal Periódicos - Capes and in the database ProQuest. The main approaches included in this theme are presented in a summarized form, as well as the research gaps in the area are identified. The results show that these concepts involve themes such as local rural development, politicization of consumption, sustainability, market niches, agroecology, territorial valorization, and institutional programs.
\end{abstract}

Keywords: Local food; local food systems; short food supply chains; family farming.

São Paulo. Vol. 23, 2020

Original Article

DOI: http://dx.doi.org/10.1590/1809-4422asoc20180248r2vu2020L5AO 


\section{Introduction}

Discussions about local food systems have been greatly encouraged in recent years, especially since the 1990s (MARTINEZ et al., 2010; AZEVEDO, 2015). Feenstra (1997) carried out one of the first reviews on this theme in the United States, where she sought to evaluate strategies and initiatives in theoretical and practical fields to promote and develop systems based on local production and consumption structures. According to her, one way to revitalize a community or region is to develop a local food economy.

With a slightly different focus but still taking the perspective of local food systems, Brown (2002) presented a review of the literature on retail and direct marketing in North America. One of her objectives was to evaluate the economic and social impact of local farmers' markets based on the argument that academic discussion of this topic was scarce. Specifically, Brown (2002) reviewed papers published from 1940 to 2000. This review showed that the literature suggests issues around the economic impact on local farmers' income, agricultural production patterns, land use, changes in consumer attitudes and consumption patterns, and social impacts.

Brown and Miller (2008) published a literature review focusing on the impacts of community-supported agriculture (CSAs) and farmers' markets on consumers, producers, and communities. They concluded that farmers' markets encourage more diversified and seasonal food production in localized systems, attracting an increasing number of buyers, which can potentially strengthen local economies. They also showed that the economic interactions in these markets are combined with a variety of social interactions linked to the local and socio-cultural context and the community.

Later, authors such as Martinez et al. (2010) and Kneafsey et al. (2013) also conducted studies with the main objective of synthesizing the theory on local food systems. Similarly, this article seeks to present the current debate regarding this theme based on a systematic review of the literature. The main objective of this review is to understand how the social category of family farming has been inserted into research on local food systems. As the discussion on family farming is recurring globally, it is interesting to verify how family farmers can dialogue with their proposed insertion in short food supply chains and local marketing circuits. To achieve the proposed objective, the methodological procedure of a systematic literature review is used following the Methodi Ordinatio (M.O) protocol proposed by Pagani, Kovaleski; and Resende (2015).

\section{Local food systems}

According to Kneafsey et al. (2013), a local food system consists of a structure in which food is produced, processed, and marketed within a defined geographical area. According to Martinez et al. (2010), these systems involve the markets of local farmers, heterogeneous products, and short food supply chains in which farmers not only produce goods but can also perform marketing functions, including storage, packaging, transport, and distribution. 
For Martinez et al. (2010), local food can be understood in part as a geographic concept that is related to the (geographic) distance between consumers and food producers. It is also related to the notion of proximity, through which the concept of local food can also be extended to those who produced the food. This concept incorporate concerns about the ethics and way of life of the farmer; considers such factors as social embeddedness, culture, and social connections; and is translated to the consumer through the information carried by the products (MARSDEN; BANKS; BRISTOW, 2000; MARTINEZ et al., 2010).

Local food systems emerge to fill the gaps left by the conventional production model, and they seek to decommoditize food and connect producers and consumers through the logic of proximity and location (FORNAZIER; BELIK, 2013). These systems seek to promote and strengthen local economies through fairer, more ethical trade relations and, above all, present themselves as alternatives to global industrial supply chains, with products that reflect the characteristics of being local, natural, healthy, and reliable (AGUIAR; DEL GROSSI; THOMÉ, 2018, p. 1).

In local food systems, one way to bring producers and consumers together is through short food supply chains (SFSCs). According to Marsden, Banks, and Bristow (2000), SFSCs seek to redefine the producer-consumer relationship by increasing transparency regarding the origin and handling of produced food products rather than using long and complex industrial chains (MARSDEN; BANKS; BRISTOW, 2000).

According to Darolt et al. (2016, p. 1), the central characteristics of short food supply chains or short marketing circuits involve such factors as social cooperation between producers and consumers, the reconnection of the production and consumption spheres under the focus of sustainability, the dynamization of local markets with territorial identities, and qualification processes.

When analyzing short food supply chains, Marsden, Banks, and Bristow (2000) identified three types of SFSCs, as follows. First, with face-to-face SFSCs, the consumer buys directly from the farmer (e.g., marketing within a farm, roadside selling, etc.). Second, in the case of spatial proximity, products come from a specific production region (or locale), and consumers are informed about the local nature of the product at the point of sale (e.g., agroecological and family farmers markets, regional brands, etc.). Third, in the case of spatially extended SFSCs, information about a food's place of production and its producers is translated for consumers outside the production region who may not have any personal experience with the region (e.g., certification labels and reputation effects).

According to Kneafsey et al. (2013), SFSCs or local food systems can generate economic gains for producers, consumers, and communities. From a family farming perspective, SFSCs offer farmers a way to diversify their production, add value to products, and ensure more sChart income (AGUIAR; DEL GROSSI; THOMÉ, 2018). The following section demonstrates the potential and possibilities of these systems for family farmers. 


\section{Family farming: new market possibilities}

According to Wanderley (1999), family farming can be understood as agriculture in which the family owns the means of production and takes over the work in the productive establishment. According to Abramovay (2010), family farming is agriculture in which ownership, management, and most of the work are carried out by individuals who maintain blood or marriage ties.

Family farmers are characterized by a specific social form of work and production that is situated in a defined geographical area and consists of the interactions of a family group, linked by kinship ties, with the land and the means of production (SCHNEIDER, 2016, p. 95).

Family farming also refers to rural employability, income generation, domestic market supply, environmental preservation, and the capacity to produce diversified crops and heterogeneous products (DELGROSSI; MARQUES, 2010). According to the 2017 Agricultural Census, $77 \%$ of agricultural establishments in Brazil are classified within the family farming segment. These farms employ more than ten million individuals, representing $67 \%$ of the total number of people employed in the country (IBGE, 2017). According to The State of Food and Agriculture report, as of 2014, there are approximately 500 million family farmers worldwide. They produce $80 \%$ of the world's food, meaning that they play a prominent role in promoting productive diversity and ensuring food security (FAO, 2014; GRAEUB et al., 2016).

Reflecting on the importance of family agriculture is essential for creating strategies to maintain and continue this social group and move towards sustainable rural development. Abramovay (1998) explained that rural development must be understood in a territorial framework in which the greatest challenge is not to integrate the farmer into industry but to create conditions for a population to value a certain territory within a varied set of activities and markets. Thus, local food systems become tools that can foster the rise and development of family farmers.

\section{Methodologial procedure}

To achieve the objective proposed in this study, that is, to identify the main theoretical elements used in discussions of local food systems related to the concept of family farming in Brazilian and international academia, the methodological procedure of a systematic literature review (SLR) is used.

According to Cordeiro, Oliveira, and Rentería (2007), an SLR is a type of scientific research that aims to gather, critically evaluate, and synthesize the results of multiple primary studies. Thus study uses the SLR protocol called M.O., which was proposed by Pagani, Kovaleski, and Resende (2015).

\section{Methodi Ordinatio (M.O)}

M.O. is a multicriteria SLR protocol for decision making in the selection of sci- 
entific papers for the composition of a bibliographic portfolio (PAGANI; KOVALESKI; RESENDE, 2015). According to de Campos et al. (2018), some SLR methods do not consider any criteria regarding the qualifications of the investigated studies but rather are exclusively based on the evaluator's subjectivity. To fill this gap, the M.O. protocol uses the three most relevant factors to be considered when choosing a study: (a) the number of citations, which demonstrates the scientific community's recognition of a given study; (b) the impact factor (metric), which indicates the importance of the journal in which the study was published; and (c) the year of publication, which reveals the topicality of the study (PAGANI; KOVALESKI; RESENDE, 2015).

According to Pagani, Kovaleski, and Resende (2015), the M.O. protocol consists of nine steps, as described below. The steps also explain the terms used, consulted databases, and procedures.

Step 1 - Establishment of the research intention. The state-of-the-art research relating the concepts and theoretical foundations for the themes of "local food systems" and "family farming" is verified.

Step 2 - Preliminary exploratory research in bibliographic databases. Combinations of the following keywords were tested in different databases: local food, local food system*, family farm, small farm, smallholder, local food systems, local food, and local marketing circuits.

Step 3 - Definition of keywords and databases. Among the databases tested, ProQuest and the search portal Periódicos CAPES (Coordination for the Improvement of Higher Education Personnel) were selected for this search because they provide a wider range of results with the used keywords and because this review includes both national and international studies. These databases are also chosen because they present results in Portuguese and English.

The article search used the following combinations: (a) (local food system* OR local food AND family farm), (b) (local food system* OR local food AND small farm*), (c) (local food systems OR local food AND family farm), and (d) (local markets) AND (family farm). The search included articles published from January 1, 2000 to December 31, 2017. After establishing the keywords and time period, final search tests were performed in the databases to ensure the consistency and quality of searches.

Step 4 - Definitive database search. Using the combinations tested in step 3, a total of 470 articles were obtained. At the time of the search, only peer-reviewed journal articles (as proposed by the M.O. protocol) were chosen, meaning that theses, dissertations, event annals, and book chapters, among others, were excluded.

Step 5 - Filtration procedure. In this stage, duplicate texts were eliminated, resulting in the exclusion of 84 texts. Articles whose title, abstract, or keywords were not related to the topic of this study; did not have the topics of family farming and local food systems as their main focus; or approached only one of the two topics without making any kind of connection between the two topics were excluded (241 texts). Finally, articles that were not sufficiently relevant or adherent to the proposed topic to be included in the bibliographic portfolio after reading the introduction and conclusion were excluded (94 
texts). This filtering resulted in a total of 51 articles composing the portfolio for this study.

Step 6 - Identification of the impact factor, year, and number of citations. This step was carried out simultaneously with step 8 . It was possible to locate the integral format of all articles, meaning that no article was excluded in this step. The articles were organized in a spreadsheet including data in the following order: title of the article, impact factor (Scientific Journal Ranking or Journal Impact Factor in the last year), number of citations, and year.

Step 7 - Classification of the articles with InOrdinatio. The equation InOrdinatio (PAGANI; KOVALESKI; RESENDE, 2015) was adopted to classify the articles. A value of ten was used for a, which refers to the degree of importance of the criterion year assigned by the researcher and ranges from one to ten.

\section{In Ordinatio $=($ fi/1000 $)+a *(10-($ year search - year of publication $)+(\Sigma \mathrm{CI})$}

\section{(Formula 1)}

Importantly, in SLR, the researcher should use a broad temporal delimitation (DE CAMPOS et al. 2018). However, some studies that are considered classics and are cited in the theoretical framework do not appear in this review. This outcome is justified because the researchers in this study set alpha $(\alpha)$ equal to ten. This value assignment means that the most recent articles are presented in the portfolio as the most relevant studies. Considering the current relevance of this subject, it is essential to assess whether the most recent articles have arrived at a more consistent theory and to understand whether they have been able to fill the research gaps proposed by classical studies, such as those of Brown (2002) and Feenstra (1997) cited above, and to identify the current research gaps in this theoretical field.

Step 8 - Location of the articles in their full format. This step was carried out simultaneously with step 6 . All of the selected articles were located in their full formats.

Stage 9 - Reading and systematically analyzing the articles. The systemic reading was performed using the 30 articles ranked highest by the InOrdinatio calculation (see step 7), that is, the studies with the greatest impact among the 51 studies included in the bibliographical portfolio.

\section{Results: state-of-the-art research relating local food systems and family farming}

The results obtained by systematically reading the articles selected for this review are presented below. Chart 1 identifies the articles classified in the top 30 by InOrdinatio in order of their year of publication. 


\section{Chart 1 - State-of-the-art of research on local agri-food systems and family farming.}

\begin{tabular}{|c|c|c|}
\hline & Article Title & Authors \\
\hline 1 & $\begin{array}{l}\text { Working Toward a Just, EquiChart, and Local Food System: The Social } \\
\text { Impact of Community-Based Agriculture }\end{array}$ & Macias (2008); \\
\hline 2 & $\begin{array}{l}\text { The impacts of local markets: A review of research on farmers markets } \\
\text { and community supported agriculture (CSA) }\end{array}$ & Brown and Miller (2008); \\
\hline 3 & $\begin{array}{l}\text { Farm to school programs: Exploring the role of regionally-based food } \\
\text { distributors in alternative agrifood networks }\end{array}$ & $\begin{array}{l}\text { Izumi, Wright, and Hamm } \\
(2010) \text {; }\end{array}$ \\
\hline 4 & $\begin{array}{l}\text { A alimentação no contexto contemporâneo: consumo, ação política e } \\
\text { sustentabilidade }\end{array}$ & Portilho e Castaneda (2011); \\
\hline 5 & $\begin{array}{l}\text { Consumer preferences for local production and other value-added label } \\
\text { claims for a processed food product }\end{array}$ & Hu et al. (2011); \\
\hline 6 & Farm to Institution: Creating Access to Healthy Local and Regional Foods & Harris et al. (2012); \\
\hline 7 & Growing local food: Scale and local food systems governance & Mount (2012); \\
\hline 8 & $\begin{array}{l}\text { Linking Local Food Systems and the Social Economy? Future Roles for } \\
\text { Farmers' Market in Alberia and British Columbia }\end{array}$ & $\begin{array}{l}\text { Wittman, Beckie, and Hergeshei- } \\
\text { mer (2012); }\end{array}$ \\
\hline 9 & $\begin{array}{l}\text { Indicações geográficas e o desenvolvimento territorial: um diálogo entre a } \\
\text { realidade europeia e brasileira }\end{array}$ & Anjos, Caldas, and Criado (2013) \\
\hline 10 & $\begin{array}{l}\text { Role of Gastronomic externality and feasibility attributes in consumer } \\
\text { demand for organic and local food: the case of honey and apples }\end{array}$ & Jensen et al. (2013) (2013); \\
\hline 11 & $\begin{array}{l}\text { Substitutes or complements? Consumer preference for local and organic } \\
\text { food attributes }\end{array}$ & Meas et al. (2014); \\
\hline 12 & $\begin{array}{l}\text { Análise sócio produtiva dos assentamentos em Cáceres, Mato Grosso: } \\
\text { Políticas Públicas para o desenvolvimento territorial }\end{array}$ & Scheuer, Botti, and Neves (2015); \\
\hline 13 & O ativismo alimentar na perspectiva do Locavorismo & Azevedo (2015); \\
\hline 14 & $\begin{array}{l}\text { Valorização de produtos alimentares tradicionais: os usos das indicações } \\
\text { geográficas no contexto brasileiro }\end{array}$ & Santos and Menasche (2015); \\
\hline 15 & $\begin{array}{l}\text { Beekeeping and Agroecological Systems for Endougenous Sustenable } \\
\text { Development }\end{array}$ & Wolff and Gomes (2015); \\
\hline 16 & $\begin{array}{l}\text { Potencialidades e dificuldades para o abastecimento da alimentação } \\
\text { escolar mediante a aquisição de alimentos da agricultura familiar em um } \\
\text { município brasileiro }\end{array}$ & Soares et al. (2015); \\
\hline 17 & $\begin{array}{l}\text { Competitiveness of small farms and innovative food supply chains: The } \\
\text { role of food hubs in creating sustainable regional and local food systems }\end{array}$ & Berti and Mulligan (2016); \\
\hline 18 & $\begin{array}{l}\text { Rebuilding local foods in Appalachia: Variables affecting distribution } \\
\text { methods of West Virginia farms }\end{array}$ & Farmer and Betz (2016); \\
\hline 19 & $\begin{array}{l}\text { Alternative Food Networks and New Producer-Consumer Relations in } \\
\text { France and in Brazil }\end{array}$ & Darolt et al. (2016); \\
\hline 20 & $\begin{array}{l}\text { Coordenação na Agricultura Familiar e o Desenvolvimento Territorial: o } \\
\text { caso das indicações geográficas para o café }\end{array}$ & Pereira (2016); \\
\hline 21 & $\begin{array}{l}\text { Mercados Imersos: uma perspectiva de análise institucional e relacional } \\
\text { das trocas econômicas e do intercâmbio mercantil }\end{array}$ & $\begin{array}{l}\text { Cassol, Salvate, and Schneider } \\
\text { (2016); }\end{array}$ \\
\hline
\end{tabular}




\begin{tabular}{|c|c|c|}
\hline & Article Title & Authors \\
\hline 22 & $\begin{array}{l}\text { Ecologização na Agricultura Familiar, feiras e produtos artesanais na } \\
\text { região Central do Rio Grande do Sul }\end{array}$ & Picolotto and Bremm (2016); \\
\hline 23 & $\begin{array}{l}\text { Agricultura Familiar, sistemas agroalimentares localizados - Sials e as } \\
\text { dinâmicas de desenvolvimento dos territórios rurais }\end{array}$ & Moraes (2016); \\
\hline 24 & $\begin{array}{l}\text { Farm Fresh Foods for Healthy Kids (F3HK): An innovative community } \\
\text { supported agriculture intervention to prevent childhood obesity in low- } \\
\text {-income families and strengthen local agricultural economies }\end{array}$ & Seguin et al. (2017); \\
\hline 25 & $\begin{array}{l}\text { Scaling-up short food supply chains? A survey study on the drivers behind } \\
\text { the intention of food producers }\end{array}$ & $\begin{array}{l}\text { Aggestam; Fleib, and Posch } \\
(2017) ;\end{array}$ \\
\hline 26 & Local beef production: What Rio Grande do Sul is waiting for? & Oliveira and Freitas (2017); \\
\hline 27 & $\begin{array}{l}\text { Farmer cooperation as a means for creating local food systems-Potentials } \\
\text { and challenges }\end{array}$ & $\begin{array}{l}\text { Lutz, Smetschka and Grima } \\
(2017) \text {; }\end{array}$ \\
\hline 28 & $\begin{array}{l}\text { Relações sociais e território: estudo no arranjo produtivo local (APL) da } \\
\text { castanha da amazônia }\end{array}$ & Justen and Souza (2017); \\
\hline 29 & $\begin{array}{l}\text { Using local family farm products for school feeding programmes: effect } \\
\text { on school menus }\end{array}$ & Soares (2017); \\
\hline 30 & State Support in Brazil for a Local Turn to Food & Matei (2017); \\
\hline
\end{tabular}

Source: Prepared by the authors, 2018.

It should be noted that Brown's (2002) study entitled "Farmers' market research" and Allen's (2010) study "Realizing justice in social local food systems" were the most cited in the international academic context. In the Brazilian academy, Schneider and Niederle were the most cited authors, but these citations are not concentrated on a specific work by these authors; instead, different studies by these authors were frequently cited.

Graph 1 shows the distribution of the articles by year of publication. The largest portion of the articles analyzed are concentrated in the years 2015 to 2017. This phenomenon occurs for two reasons. First, a value of ten was assigned to alpha $(\alpha)$ in the InOrdinatio equation, which therefore favors the most recent studies to a certain extent. Second, this subject has become more widespread in recent years as, for example, the United Nations declared 2014 the International Year of Family Farming. 


\section{Graph 1 - Average number of publications per year}

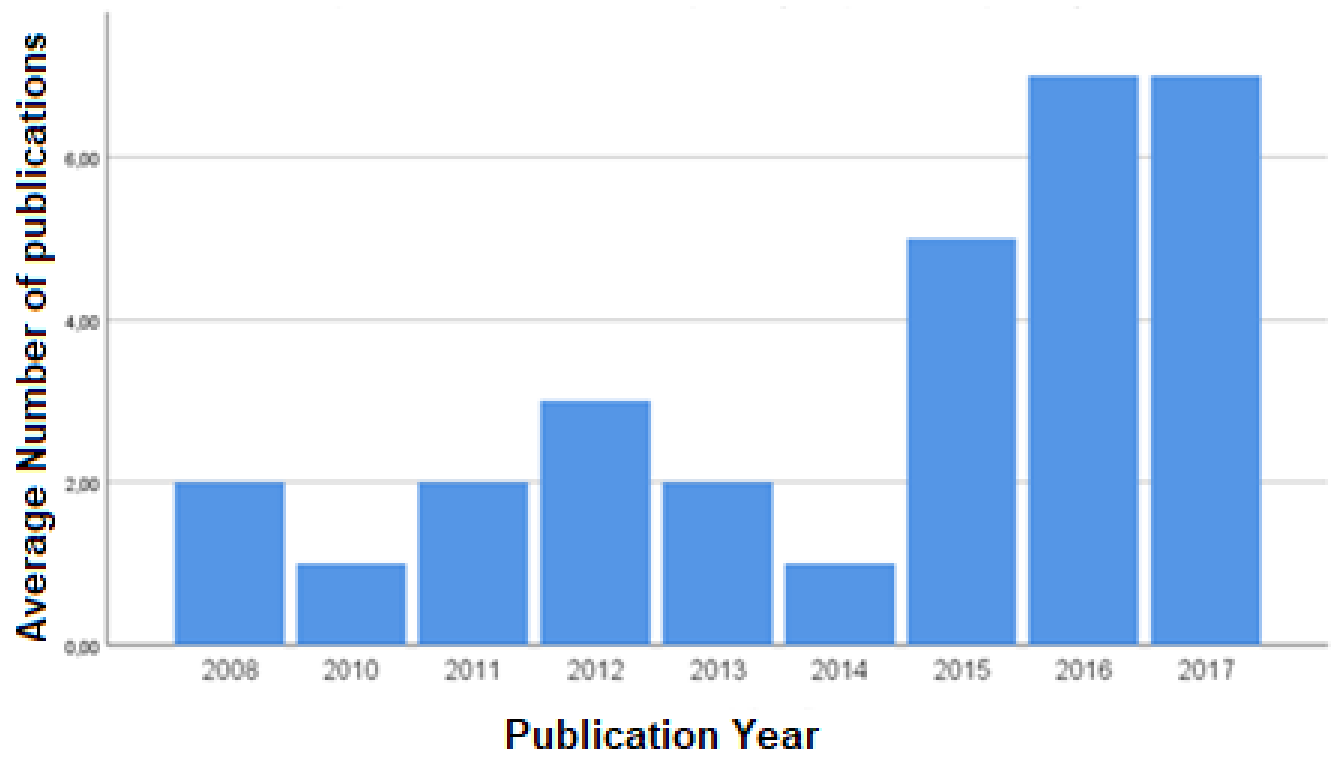

Source: Prepared by the authors, 2018.

Chart 2 shows the journals in which the articles included in this review were published. Noticeably, the studies fall within the scope of research on public policy, rural sociology, geography, economics, nutrition and health, sustainability, and consumption.

\section{Chart 2 - Number of publications per journal}

\begin{tabular}{|c|c|}
\hline \multicolumn{1}{|c|}{ Journal } & Published articles \\
\hline Advances in Nutrition & 1 \\
\hline Agriculture & 1 \\
\hline Agriculture and Human Values & 2 \\
\hline Agroecology and Sustainable Food Systems & 1 \\
\hline Ambiente \& Sociedade & 2 \\
\hline American Journal of Agricultural Economics & 2 \\
\hline BMC public health & 1 \\
\hline British Food Journal & 1 \\
\hline Ciência \& Saúde Coletiva & 2 \\
\hline Ciências da Administração & 1 \\
\hline Cuadernos de Desarrollo Rural & 1 \\
\hline
\end{tabular}




\begin{tabular}{|c|c|}
\multicolumn{1}{c|}{ Journal } & Published articles \\
\hline Dados, Revista de Ciências Sociais & 1 \\
\hline European Review of Agricultural Economics & 1 \\
\hline International Journal of Consumer Studies & 1 \\
\hline Journal of rural studies & 2 \\
\hline Política \& Sociedade & 3 \\
\hline Redes & 1 \\
\hline Revista em Agronegócio e Meio Ambiente & 1 \\
\hline Revista Geografia Academica & 1 \\
\hline Rural Sociology & 1 \\
\hline Social Science Quarterly & 1 \\
\hline Sustainability & 2 \\
\hline
\end{tabular}

Source: Prepared by the authors, 2018.

This theme is multidisciplinary, as can be seen in Chart 2, which presents the variety of journals in which the articles that make up the portfolio of analysis were published. Thus, it was necessary to first check the central theme of each article and then divide them into groups according to their themes. Chart 3 presents the main themes and subthemes that were addressed by the analyzed studies. Each one of these topics is briefly addressed in this work with the objective of describing the main discussions related to this systematic review.

Chart 3 - Themes and sub-themes identified in the literature

\begin{tabular}{|c|c|}
\hline \multicolumn{2}{|c|}{ State-of-the-art research relating local systems and family farming } \\
\hline Central themes & References \\
\hline Creating value through local food systems & $\begin{array}{l}\text { Berti and Mulligan (2016); Meas et al. } \\
\text { (2014); Anjos, Caldas, and Criado (2013); } \\
\text { Mount (2012); Hu et al. (2011) }\end{array}$ \\
\hline $\begin{array}{l}\text { Analysis of the relationship between produc- } \\
\text { ers and consumers involved in local food } \\
\text { systems }\end{array}$ & $\begin{array}{l}\text { Darolt et al. (2016); Farmer and Betz (2016); } \\
\text { Azevedo (2015); Tveit (2013); Portilho and } \\
\text { Castaneda (2011) }\end{array}$ \\
\hline Social, economic, and environmental impacts & $\begin{array}{l}\text { Aggestam, Fleib, and Posch (2017); Se- } \\
\text { guin et al. (2017); Wittman, Beckie, and } \\
\text { Hergesheimer (2012); Brown and Miller } \\
\text { (2008); Macias (2008) }\end{array}$ \\
\hline Sub-themes noted by the literature & References \\
\hline Feasibility of creating local food systems & De Oliveira and Freitas (2017) \\
\hline
\end{tabular}




\begin{tabular}{|l|l|}
\hline $\begin{array}{l}\text { Organization and cooperation in local food } \\
\text { systems }\end{array}$ & $\begin{array}{l}\text { Lutz, Smetschka, and Grima (2017); Pereira } \\
\text { et al. (2016); Santos and Menasche (2015) }\end{array}$ \\
\hline $\begin{array}{l}\text { Characteristics of specific local production } \\
\text { systems }\end{array}$ & $\begin{array}{l}\text { Simão Justen and Souza (2017); Cassol, } \\
\text { Salvate, and Schneider (2016); De Moraes } \\
(2016) \text {; Picolotto and Bremm (2016); Wolff } \\
\text { and Gomes (2015); }\end{array}$ \\
\hline Public policies and institutional programs & $\begin{array}{l}\text { Matei (2017); Soares (2017); Scheuer, Botti, } \\
\text { and Neves (2015); Soares et al. (2015); Har- } \\
\text { ris et al. (2012); Izumi, Wright, and Hamm } \\
(2010) ;\end{array}$ \\
\hline
\end{tabular}

Source: Prepared by the authors, 2018.

\section{Creating value through local food systems}

According to Hu et al. (2011), consumer interest in locally grown foods has grown over the past decade. To meet this demand, farmers are increasingly attracted by the potential of local foods as a value-added alternative to low profitability and diminishing prospects for conventional commodity production (MOUNT, 2012).

Meas et al. (2014) noted in their research that consumers are willing to pay more for locally produced food, provided that it is clearly labelled as a product of local family farmers, because of the notion that they are supporting small producers. In other words, consumers are searching for the consumption sphere and getting closer to producers. Thus, as suggested by Anjos, Caldas, and Criado (2013), family farming and Geographical Indication (GI) labels may be strategies to add value to local products produced by family farmers in addition to the possibility of assigning premium prices to food.

\section{Feasibility of creating local food systems}

De Oliveira and Freitas (2017) sought to demonstrate the potential of investment in local meat production in Rio Grande do Sul in the municipalities of Alegrete, Dom Pedrito, Bagé, Santa Maria, and Pelotas. According to the authors, the creation of local markets for meat is justified by the fact that these municipalities have favorable climates and soil for raising cattle, high genetic quality of cattle breeds, traditions around management and cooking, and consumers with relatively high income.

According to de Oliveira and Freitas (2017), Rio Grande do Sul has the potential to develop short food supply chains in the market for meat, reduce intermediaries, and capture profits from marketing meat in the region. In addition to providing several products with high added value, selling meat in local markets can contribute to the development of family farmers and environmental preservation in Rio Grande do Sul.

This example previously reported by the authors demonstrates that to create markets or supply chain structures based on locality, it is necessary to take into consideration issues such as the region's productive potential, consumer market analysis, regional traditions and cultures, and market and social factors. 


\section{Relationship between producers and consumers in local food systems}

The relationship between producers and consumers is built on bonds of trust and proximity, mainly through a face-to-face dynamic (AZEVEDO, 2015). Motivated by distrust of the agri-food sector, consumers need to be ever closer to the point of production and follow the production and food handling processes, as suggested by the theory of SFSCs (AZEVEDO, 2015).

Consumers and producers in local food systems are involved in relationships that include valuing local products and knowledge, trust, links to sustainable production practices, and promoting social justice by supporting family farmers' markets (AZEVEDO, 2015; DAROLT et al., 2016; FARMER; BETZ, 2016). These actors perceive producing and feeding themselves as a political act that is positioned against the practices adopted by the conventional system (PORTILHO; CASTANEDA, 2011).

\section{Organization and cooperation in local food systems}

Farmers in local food systems are also likely to face challenges related to, for example, the scale of production, costs, logistics, access to credit, access to technology, bargaining power, and accessing certain markets (SANTOS; MENASCHE, 2015; LUTZ; SMETSCHKA; GRIMA, 2017). For Lutz, Smetschka, and Grima (2017), one way to tackle these obstacles is through organization and cooperation between farmers, consumers, and public institutions.

Cooperation is not only about reducing production costs; it can also help farmers to organize certain markets. A clear example is the use of GI registration. According to Santos and Menasche (2015), one requirement for the process of building a GI is establishing a formal group, such as an association or cooperative. For Pereira et al. (2016), cooperation can be considered an efficient means to leverage territories and allow local products to be recognized and sold in different markets, allowing family farmers to access these markets.

\section{Characteristics of specific local production systems}

Simão Justen and Souza (2017) evaluated the local productive arrangement of the Brazil nut in Brazil's Acre State. Cassol, Salvate, and Schneider (2016) analyzed the construction process and dynamics of markets, such as the Passo Fundo/RS Small Producer Market. Moraes (2016) focused on agri-food systems in the Vale do Caí region. Picolotto and Bremm (2016) reflect on the transition to agroecological agriculture among family farmers and land reform settlers in the central region of Rio Grande do Sul and on the experience of fairs as a space for social exchanges and cultural signs between producers and consumers. They also consider fairs as spaces for social exchanges and cultural signs between producers and consumers. Finally, Wolff and Gomes (2015) focus on beekeeping activities carried out by family farmers in southern Brazil.

Local food systems must comprise socially engaged actors (producers, consumers, and the public and private sectors) to strengthen local productive activities, establish 
solid relationships between consumption and production, and, consequently, improve farmers' living conditions (WOLFF; GOMES, 2015).

Additionally, these systems can strengthen other local productive arrangements, such as rural or gastronomic tourism (CASSOL; SALVATE; SCHNEIDER, 2016). Thus, creating social spaces where it is possible to not only sell products directly but also to provide exchanges of information and cultural signs is a fundamental characteristic of these systems.

\section{Public policies and institutional programs}

pite the social benefits that are attributed to local food systems, some producers and consumers are unable to access local markets, mainly for reasons related to their low incomes (IZUMI; WRIGHT; HAMM, 2010). Thus, institutional programs and public policies to foster local production are extremely important to promote justice and social equity among individuals and strengthen the local social fabric (HARRIS et al., 2012).

On the subject of institutional markets, the greatest number of researchers (5) concentrated on the Farm-to-School programs in the United States, and the Food Acquisition Program/Programa de Aquisição de Alimentos and the National School Feeding Program/Programa Nacional de Alimentação Escolar in studies focused on Brazil. The authors agree that family farming purchasing programs can promote healthy and diversified food for institutional consumers, contribute to the democratization of food, support food and nutrition security, reduce poverty among family farmers, and contribute to local development (IZUMI; WRIGHT; HAMM, 2010; HARRIS et al., 2012; SCHEUER; BOTTI; NEVES, 2015; SOARES, 2017).

\section{Research gaps}

In addition to verifying the main discussions on the theme of local food systems and family farming, this research can also verify the research gaps, that is, themes that can be further researched to enrich the main topic of study. Chart 4 presents the main research gaps identified in this SLR. 


\section{Chart 4 - Research gaps}

\begin{tabular}{|c|c|c|}
\hline Themes & \multicolumn{1}{c|}{ Gaps } \\
\hline $\begin{array}{c}\text { Creating value } \\
\text { through local food } \\
\text { systems }\end{array}$ & $\begin{array}{l}\text { (a) rearch assessing whether large-scale production causes local } \\
\text { consumers' perceptions of various local designations (MEAS et al., 2015); } \\
\text { and (c) research exploring farmers' views on value creation along the } \\
\text { production chain (BERTI; MULLIGAN, 2016). }\end{array}$ \\
\hline $\begin{array}{c}\text { Analysis of the } \\
\text { relationship be- } \\
\text { tween producers } \\
\text { and consumers } \\
\text { involved in local } \\
\text { food systems }\end{array}$ & $\begin{array}{l}\text { (a) studies investigating the factors that influence producers' marketing } \\
\text { decisions in local systems (PORTILHO; CASTANEDA, 2011); and (b) } \\
\text { studies that investigate the politicization of consumption as a trend in } \\
\text { contemporary societies as well as the specificities of this phenomenon in } \\
\text { the Brazilian context (PORTILHO; CASTANEDA, 2011). }\end{array}$ \\
$\begin{array}{c}\text { Social, economic, } \\
\text { and environmental } \\
\text { impacts }\end{array}$ & $\begin{array}{l}\text { (a) studies that examine marketing relationships in local systems and } \\
\text { their impacts on the environment (BROWN; MILLER, 2008); and (b) } \\
\text { studies that investigate the relationship between local production mod- } \\
\text { els and the equity in local food distribution and marketing (MACIAS, } \\
\text { 2008). }\end{array}$ \\
\hline $\begin{array}{c}\text { Organization and } \\
\text { cooperation in lo- } \\
\text { cal food systems }\end{array}$ & $\begin{array}{l}\text { (a) studies on existing forms of cooperation in local food systems (LUTZ; } \\
\text { SMETSCHKA; GRIMA, 2017); and (b) broader studies on GIs used by } \\
\text { family farmers and on the ways to organize productive actors in local food } \\
\text { systems (PEREIRA et al., 2016). }\end{array}$ \\
\hline $\begin{array}{c}\text { Characteristics of } \\
\text { specific local pro- } \\
\text { duction systems }\end{array}$ & $\begin{array}{l}\text { (a) work analyzing the coexistence of alternative markets with con- } \\
\text { ventional markets and hybrid market forms (CASSOL; SALVATE; } \\
\text { SCHNEIDER, 2016). }\end{array}$ \\
\hline $\begin{array}{l}\text { (a) studies describing and analyzing programs on an individual basis to } \\
\text { understand whether they contribute to the development of short chains } \\
\text { and more sustainable local systems. }\end{array}$ \\
\hline
\end{tabular}

Source: Created by the authors, 2020 . 


\section{Conclusions}

Local food systems encompass concepts that are closely related to local rural development, sustainability, institutional markets, local production arrangements, quality and organic production, economic impacts on local communities, and changes in consumption patterns.

This study's main contribution is identifying the methods used by the most recent studies on this topic and the main discussions and research gaps identified in this theoretical field. Work in this field has expanded in recent years and falls within the scope of several fields of research, including geography, sociology, public policy, agronomy, and nutrition, among others.

The objective of this research was achieved in that the study verified the state-ofthe-art of studies related the concepts of "local agri-food systems" and "family farming" and highlighted the main themes being discussed and the research gaps in the literature. We suggest that future research focus on the gaps identified by this study.

Some limitations of the systematic review method adopted here are that it identifies references that have greater impacts and are more recent, and it is limited to the English and Portuguese languages, meaning that it excludes research in other languages. The criteria for the inclusion or exclusion of articles also depend on the researcher's reading and level of theoretical knowledge on the subject. In addition, this method does not consider technical studies, such as reports, annals of events, and books. However, as Gomes and Caminha (2014, p. 397) report, "well-structured reviews may help in updating and building new guidelines for professional performance or going to the field in search of solutions for original articles." In other words, this methodology is useful and can support other research methodologies, such as field research. However, even with these limitations, this method enables the systematic identification of themes that are being published in journals with greater impacts, thus helping to see the state-of-the-art work on this topic and the research gaps and to understand the themes and research suggestions.

\section{Acknowledgments}

This work was carried out with the support of the Coordination for the Improvement of Higher Education Personnel - Brazil (CAPES) / Coordenação de Aperfeiçoamento de Pessoal de Nível Superior - CAPES - Financing Code 001.

\section{References}

ABRAMOVAY, R. Para juntar economia e ética, sociedade e natureza. 2010. Avaible: $<$ http:// ricardoabramovay.com/entrevistas-agricultura-familiar/>. Access:25/07/2018. 
ABRAMOVAY, R. Agricultura familiar e desenvolvimento territorial. Reforma agrária, v. 28, n. 1, p. 2, 1998.

AGUIAR, L. C.; DELGROSSI, M. E.; THOMÉ, K. M. Short food supply chain: characteristics of a family farm. Ciência Rural, v. 48, n. 5, 2018.

ANJOS, F. S.; AGUILAR CRIADO, E.; CALDAS, N. V. Indicações geográficas e desenvolvimento territorial: um diálogo entre a realidade europeia e brasileira. Dados, Revista de Ciências Sociais, 56 (1), 207-236., 2013.

ANJOS, F. S.; CALDAS, N. V. A dinâmica dos canais curtos de comercialização: o caso do Projeto Campagna Amica na Itália. Sociedade e Estado, v. 32, n. 3, p. 771-792, 2017.

AZEVEDO, E. O Ativismo Alimentar na perspectiva do Locavorismo. Ambiente $\mathbb{\&}$ Sociedade, v. 18, n. 3, p. 81-98, 2015.

BROWN, A. Farmers' market research 1940-2000: An inventory and review. American journal of alternative agriculture, v. 17, n. 4, p. 167-176, 2002.

BROWN, C.; MILLER, S. The impacts of local markets: a review of research on farmers markets and community supported agriculture (CSA). American Journal of Agricultural Economics, v. 90, n. 5, p. 1298-1302, 2008.

BELIK, W.; FORNAZIER, A. Políticas Públicas e a construção de novos mercados para a agricultura familiar: analisando o caso da alimentação escolar no município de São Paulo. Raízes. v. 36, n. 2, p. 70-81, jul-dez.2016.

BERTI, G.; MULLIGAN, C. Competitiveness of small farms and innovative food supply chains: The role of food hubs in creating sustainable regional and local food systems. Sustainability, v. 8, n. 7, p. 616, 2016.

CASSOL, A; SALVATE, N.; SCHNEIDER, S. Mercados Imersos: uma perspectiva de análise institucional e relacional das trocas econômicas e do intercâmbio mercantil. Política $\&$ Sociedade, v. 15, n. 33, p. 314, 2016.

CORDEIRO, A. M. et al. Systematic review: a narrative review. Revista do Colégio Brasileiro de Cirurgiões, v. 34, n. 6, p. 428-431, 2007.

CHIFFOLEAU, Y.; PREVOST, B. Les circuits courts, des innovations sociales pour une alimentation durable dans les territoires. Norois. Environnement, aménagement, société, n. 224, p. $7-20,2012$.

DAROLT, M. R. et al. Alternative food networks and new producer-consumer relations in France and in Brazil. Ambiente \& Sociedade, v. 19, n. 2, p. 1-22, 2016.

DE CAMPOS, E. A. R. et al. Construction and qualitative assessment of a bibliographic portfolio using the methodology Methodi Ordinatio. Scientometrics, v. 116, n. 2, p. 815-842, 2018. 
DE GODOI PEREIRA, M. E. B. et al. Coordenação na Agricultura Familiar e o Desenvolvimento Territorial: o caso das indicações geográficas para o café. Política $\&$ Sociedade, v. 15, p. 131, 2016.

DE MORAES, J. L. A. Agricultura Familiar, Sistemas Agroalimentares Localizados (SIALs) e as Dinâmicas de Desenvolvimento dos Territórios Rurais. Redes, v. 21, n. 3, p. 238-256, 2016.

DEL GROSSI, M. E.; DE AZEVEDO MARQUES, V. PM. Agricultura familiar no censo agropecuário 2006: o marco legal e as opções para sua identificação. Estudos Sociedade e Agricultura, 2010.

DE OLIVEIRA, T. E.; FREITAS, D. S. Local beef production: what Rio Grande do Sul is waiting for? Revista em Agronegócio e Meio Ambiente, v. 10, n. 2, p. 321, 2017.

FAO. Programa para el Censo Agropecuario Mundial. SOFA-2014. Avaible:<http://www.fao. org/world-census-agriculture/es/>. Access:29/07/2018.

FARMER, J. R.; BETZ, M. E. Rebuilding local foods in Appalachia: Variables affecting distribution methods of West Virginia farms. Journal of rural studies, v. 45, p. 34-42, 2016.

FEENSTRA, G. W. Local food systems and sustainable communities. American journal of alternative agriculture, v. 12, n. 1, p. 28-36, 1997.

FORNAZIER, A.; BELIK, W. Produção e consumo local de alimentos: novas abordagens e perspectivas para as políticas públicas. Segurança Nutricional e Alimentar, v. 20, n. 2, p. 204-218, 2013.

GOMES, I. S.; CAMINHA, I. O. Guia para estudos de revisão sistemática: uma opção metodológica para as Ciências do Movimento Humano. Movimento, Porto Alegre, v. 20, n. 01, p. 395-411, jan/mar de 2014.

GRAEUB, B. E. et al. The state of family farms in the world. World development, v. 87, p. 1-15, 2016.

HARRIS, D. et al. Farm to institution: Creating access to healthy local and regional foods. Advances in Nutrition, v. 3, n. 3, p. 343-349, 2012.

HU, W. et al. Consumer preferences for local production and other value-added label claims for a processed food product. European Review of Agricultural Economics, v. 39, n. 3, p. 489-510, 2011.

IBGE. Censo Agropecuário 2017: resultados definitivos. Brasil, 2017. Avaible:https://sidra. ibge.gov.br/pesquisa/censo-agropecuario/censo-agropecuario-2017. Acesso em 31 Jan. 2020.

IZUMI, B.T.; WRIGHT, D. W.; HAMM, M. W. Farm to school programs: Exploring the role of regionally-based food distributors in alternative agrifood networks. Agriculture and Human Values, v. 27, n. 3, p. 335-350, 2010. 
KENEAFSEY, M. et al. Short Food Supply Chains and Local Food Systems in the UE. A State of Play of their Socio-Economic Characteristics. JRC SCIENTIFIC AND POLICY REPORTS. União Europeia. 2013. Avaible: $\leq$ http://publications.jrc.ec.europa.eu/repository/bitstream/ JRC80420/final\%20ipts\%20jrc\%2080420\%20(online).pdf>. Acesso em 01/05/2018.

LUTZ, J.; SMETSCHKA, B.; GRIMA, N. Farmer Cooperation as a Means for Creating Local Food Systems—Potentials and Challenges. Sustainability, v. 9, n. 6, p. 925, 2017.

MACIAS, T. Working toward a just, equiChart, and local food system: The social impact of Community-Based agriculture. Social science quarterly, v. 89, n. 5, p. 1086-1101, 2008.

MARTINEZ, S. et al. Local food systems: Concepts, impacts, and issues, ERR 97. US Department of Agriculture, Economic Research Service, v. 5, 2010.

MARSDEN, T.; BANKS, J.; BRISTOW, G. Food supply chain approaches: exploring their role in rural development. Sociologia ruralis, v. 40, n. 4, p. 424-438, 2000.

MATEI, A. P. et al. State Support in Brazil for a Local Turn to Food. Agriculture, v. 7, n. 1, p. $5,2017$.

MEAS, T. et al. Substitutes or complements? Consumer preference for local and organic food attributes. American Journal of Agricultural Economics, v. 97, n. 4, p. 1044-1071, 2014.

MOUNT, P. Growing local food: scale and local food systems governance. Agriculture and Human Values, v. 29, n. 1, p. 107-121, 2012.

PICOLOTTO, E. L.; BREMM, C. Ecologização na Agricultura Familiar, feiras e produtos artesanais na região Central do Rio Grande do Sul 1. Política $\&$ Sociedade, v. 15, p. 104, 2016.

PORTILHO, F.; CASTAÑEDA, M.; CASTRO, Inês Rugani Ribeiro de. A alimentação no contexto contemporâneo: consumo, ação política e sustentabilidade. Ciência $\mathbb{\&}$ Saúde Coletiva, v. 16, p. 99-106, 2011.

SANTOS, J. S.; MENASCHE, R. Valorização de produtos alimentares tradicionais: os usos das indicações geográficas no contexto brasileiro. Cuadernos de Desarrollo Rural= International Journal of Rural Development, v. 12, n. 75, p. 21, 2015.

SCHEUER, J. M.; BOTTI, N. S.; DA SILVA NEVES, S. M. A. Socio-productive an alysis of settlements in Caceres, Mato Grosso: public policies for territorial development/Análisis socio- productivos de los asentamientos en Caceres, Mato Grosso. Revista Geográfica Acadêmica, v. 9, n. 2, p. 141-153, 2015.

SCHNEIDER, S. Mercados e agricultura familiar. Construção de Mercados e Agricultura Familiar: desafios para o desenvolvimento rural. Porto Alegre: Editora da UFRGS, p. 93-140, 2016.

SEGUIN, R. A. et al. Farm Fresh Foods for Healthy Kids (F3HK): An innovative community supported agriculture intervention to prevent childhood obesity in low-income families and 
strengthen local agricultural economies. BMC public health, v. 17, n. 1, p. 306, 2017.

SOARES, P. et al. Potencialidades e dificuldades para o abastecimento da alimentação escolar mediante a aquisição de alimentos da agricultura familiar em um município brasileiro. Ciência \& Saúde Coletiva, v. 20, p. 1891-1900, 2015.

SOARES, P. et al. Using local family farm products for school feeding programmes: effect on school menus. British Food Journal, v. 119, n. 6, p. 1289-1300, 2017.

STARR, A. et al. Sustaining local agriculture barriers and opportunities to direct marketing between farms and restaurants in Colorado. Agriculture and Human Values, v. 20, n. 3, p. 301321, 2003.

SIMÃO JUSTEN, G.; PAES-DE-SOUZA, M. Relações Sociais e Território: estudo no Arranjo Produtivo Local (APL) da castanha-da-Amazônia. Revista de Ciências da Administração, v. 19, n. 47, 2017.

USDA - United States Department of Agriculture. Local Food Systems: Concepts, Impacts, and Issues. Martinez S. et al. Economic Research Service, Economic Research Report 97; 2010.

WANDERLEY, M. N. B. Raízes históricas do campesinato brasileiro. Agricultura familiar: realidades e perspectivas, v. 3, p. 21-55, 1999.

WOLFF, L. F; GOMES, J. C. C. Beekeeping and Agroecological Systems for Endogenous Sustainable Development. Agroecology and Sustainable Food Systems, v. 39, n. 4, p. 416-435, 2015. 
Amanda Borges de Souza

$\square$ borgessouza.amanda@gmail.com

ORCiD: https://orcid.org/0000-0002-4474-1412
Submitted on: 16/10/2018

Accepted on: 18/06/2020

2020;23:e02482

\section{Armando Fornazier}

$\square$ armandouenf@yahoo.com.br

ORCiD: https://orcid.org/0000-0002-6707-9601

\section{Mauro Eduardo Delgrossi}

๑delgrossi@unb.br

ORCiD: https://orcid.org/0000-0003-0091-0701

How to cite: SOUZA, A. B.; FORNAZIER, A.; DELGROSSI, M. E. Local Food Systems: potential for new market connections for family farming. Ambiente $\mathbb{\&}$ Sociedade. São Paulo, v. 23, p. 1-20, 2020. 


\title{
Sistemas agroalimentares locais: possibilidades de novas conexões de mercados para a agricultura familiar
}

\author{
Amanda Borges de Souza \\ Armando Fornazier \\ Mauro Eduardo Delgrossi
}

São Paulo. Vol. 23, 2020

Artigo Original
Resumo: Nos últimos anos, o conceito de sistemas agroalimentares locais passou a ser visualizado como uma nova possibilidade na criação de mercados para agricultura familiar. Estes sistemas são baseados em estruturas locais de produção e consumo, com enfoque principal em sustentabilidade, localidade e proximidade. É essencial compreender a dinâmica destes sistemas e seu impacto no contexto dos agricultores familiares. Assim, o presente artigo busca identificar na literatura as principais teorias e conceitos utilizados na análise sobre os "sistemas agroalimentares locais", verificando o estado da arte dos seus elementos teóricos relacionados ao conceito de "agricultura familiar" na academia brasileira e internacional. O procedimento metodológico empregado foi a revisão sistemática da literatura seguindo o protocolo Methodi Ordinatio, abrangendo 30 artigos indexados no portal de buscas Periódicos - Capes e na base de dados ProQuest. São apresentados de forma sintetizada as principais abordagens inseridas nesta temática, bem como identificadas as lacunas de pesquisa na área. Os resultados apontam que estes conceitos envolvem temas como desenvolvimento rural local, politização do consumo, sustentabilidade, nichos de mercado, agroecologia, valorização de territórios, e programas institucionais.

Palavras-chave: Comida local; sistemas agroalimentares locais; circuitos curtos de comercialização; agricultura familiar.

Como citar: SOUZA, A. B; FORNAZIER, A.; DELGROSSI, M. E. Sistemas agroalimentarios locales: posibilidades de nuevas conexiones de mercado para la agricultura familiar. Ambiente $\mathbb{\&}$ Sociedade. São Paulo, v. 23, p. 1-20, 2020. 


\title{
Sistemas agroalimentarios locales: posibilidades de nuevas conexiones de mercado para la agricultura familiar
}

\author{
Amanda Borges de Souza \\ Armando Fornazier \\ Mauro Eduardo Delgrossi
}

São Paulo. Vol. 23, 2020

Artículo original
Resumen: En los últimos años, el concepto de sistemas agroalimentarios locales se ha visto como una nueva posibilidad en la creación de mercados para la agricultura familiar. Estos sistemas se basan en estructuras locales de producción y consumo, con un enfoque principal en la sostenibilidad, la localidad y la proximidad. Es esencial comprender la dinámica de estos sistemas y su impacto en el contexto de los agricultores familiares. Así, este artículo busca identificar en la literatura las principales teorías y conceptos utilizados en el análisis de los "sistemas agroalimentarios locales", verificando el estado del arte de sus elementos teóricos relacionados con el concepto de "agricultura familiar" en la academia brasileña e internacional. El procedimiento metodológico empleado fue una revisión sistemática de la literatura siguiendo el protocolo Methodi Ordinatio, que abarca 30 artículos indexados en el portal de búsqueda Periódicos - Capes y en la base de datos ProQuest. Los principales enfoques incluidos en este tema se presentan en forma de resumen, así como se identifican los problemas de investigación en el área. Los resultados muestran que estos conceptos involucran temas como el desarrollo rural local, la politización del consumo, la sostenibilidad, los nichos de mercado, la agroecología, la valorización territorial y los programas institucionales.

Como citar: SOUZA, A. B; FORNAZIER, A.; DELGROSSI, M. E. Sistemas agroalimentarios locales: posibilidades de nuevas conexiones de mercado para la agricultura familiar. Ambiente $\&$ Sociedade. São Paulo, v. 23, p. 1-20, 2020. 